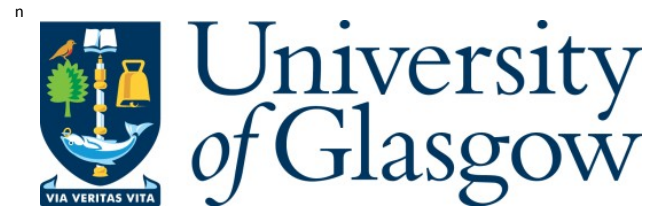

Bayer, P., and U rpelainen, J. (2016) It is all about political incentives: democracy and the renewable feed-in tariff. J ournal of Politics, 78(2), pp. 603-619.

There may be differences between this version and the published version. $Y$ ou are advised to consult the publisher's version if you wish to cite from it.

http://eprints.gla.ac.uk/115150/

Deposited on: 03 M arch 2016

Enlighten - R esearch publications by members of the U niversity of Glasgow http://eprints.gla.ac.uk 


\title{
It's All About Political Incentives: Democracy and the Renewable Feed-In Tariff
}

\author{
November 7, 2015
}

Short title: Democracy and the Renewable Feed-In Tariff

\section{Contact details:}

Patrick Bayer (corresponding author)

School of Social and Political Sciences

University of Glasgow

Adam Smith Building

Glasgow, G12 8RT

Scotland, United Kingdom

Email: Patrick.Bayer@glasgow.ac.uk (starting January 2016; to be used for publication)

Email: patrickbayer@wustl.edu (to be used for internal communication prior to January 2016)

Johannes Urpelainen

Department of Political Science

Columbia University

420W 118th Street

712 IAB

New York, NY 10027

United States of America

Email: ju2178@columbia.edu 


\begin{abstract}
Demand for renewable energy is booming. Scholars often attribute this success to feed-in tariffs (FITs), which mandate that energy utilities pay a premium to renewable electricity producers and guarantee grid access for them. Why have so many countries, including least developed ones, adopted these policies? We hypothesize that democratic governments have political incentives to adopt the FIT because it improves environmental quality, promotes rural development, and distributes electricity generation profits from large utilities to independent producers. We analyze global data on FIT adoption, 1990-2012, and find that the association between democratic regime type and FIT adoption overwhelms all other covariates. The effect is specific to the FIT and does not exist for renewable portfolio standards or public competitive bidding for renewable energy contracts. Consistent with theories of distributive politics, among democracies, institutional malapportionment in favor of rural political constituencies favors FIT adoption.
\end{abstract}

Keywords: political institutions; comparative politics; renewable energy policy; feed-in tariffs; environmental policy.

Footnote for supplementary materials: A supplementary appendix is available online from the journal's website. Data and replication files are available in the JOP Data Archive on Dataverse at http://thedata.harvard.edu/dnv/dv/jop. Patrick Bayer acknowledges financial support from the German Academic Exchange Service (DAAD) for a postdoctoral research fellowship. 
Solving climate change requires a transition from fossil fuels to clean energy. While multilateral climate negotiations have stalled, many countries have implemented national renewable energy policies, turning the focus of environmental policy from international relations to comparative politics. By the end of 2012, for example, 60 countries had implemented a "feed-in tariff" (FIT) that forces electricity consumers to pay a premium for power generated from renewable energy sources (REN21, 2012). Of the 60 countries with an FIT, 39 countries are not OECD members. FIT countries are now found on all continents of the world, with many African countries included in this group. Moreover, the FIT appears highly effective (Couture and Gagnon, 2010; Mitchell, Bauknecht, and Connor, 2006; Smith and Urpelainen, 2014). According to the Bloomberg New Energy Finance database, "FITs have driven $64 \%$ of global wind and $87 \%$ of global photovoltaic capacity" (UNEP, 2012: 5). In recent years, forms of renewable energy, with wind and solar as forerunners, have grown exponentially (REN21, 2012).

Initially, the rapid globalization of the FIT seems puzzling. Why are even least developed countries outside the OECD implementing ambitious regulatory policies to promote renewable energy? Given the cost of promoting renewable electricity generation and strong opposition by powerful interest groups such as the heavy industry and energy utilities (Lipp, 2007; Stenzel and Frenzel, 2008), it is striking how fast the FIT has spread outside pioneering countries such as Germany.

To solve this puzzle, we argue that the FIT is uniquely attractive to democratic countries. It is perhaps the most effective single policy available to a government interested in clean energy (Mendonça, 2007). By implementing an FIT, a democratic government can address pollution problems that cause significant negative externalities. Since the policy favors renewable electricity at the expense of coal, it has clear positive effects on air quality, a national public good. In democratic systems, where public good provision is essential for the government's political survival (Lake and Baum, 2001), these benefits are politically valuable. ${ }^{1}$

The FIT's environmental effectiveness alone is not enough to explain its rapid global adoption by democracies, because other policy instruments are also available. However, the FIT has politically

\footnotetext{
${ }^{1}$ Public goods play an important role in theories that emphasize the democratic advantage in environmental policy (Congleton, 1992; Payne, 1995; Neumayer, 2002; Li and Reuveny, 2006), though some scholars report weak effects (Midlarsky, 1998; Ward, 2008).
} 
useful distributive effects. Since the FIT is available to anyone interested in renewable electricity generation, it encourages the kind of decentralized power production that benefits rural constituencies in particular. The FIT allows the government to reap political benefits from large numbers of people who benefit from these projects. In Germany, for example, a large number of farmers reap handsome profits from solar electricity generation under the FIT (Vasagar, 2013). These processes are valuable to any government that worries about regional decline or disparities within the country. By creating new constituencies, the government can overcome political opposition by entrenched interests and implement policy despite the lobbying power of the heavy industry and energy utilities. Finally, the availability of the FIT to independent power producers means that the policy instrument distributes wealth from large utilities to a much larger mass of small producers, especially in rural areas, where the potential for renewable energy generation is large. In a democratic system, such redistribution of wealth and influence is politically expedient (Acemoglu and Robinson, 2001; Boix, 2003; Meltzer and Richard, 1981).

To test these hypotheses, we use data for years 1990 to 2012 that have global geographic coverage. While many studies of renewable energy are limited to industrialized countries, we consider all countries of the world. Before 1990, the FIT did not play a role in national renewable energy policy. By the year 2012, there were 60 such policies at the national level. We examine how democratic political institutions and other variables influence the probability of FIT adoption. The effect of democracy overwhelms the influence of all other explanatory variables in our models. In expectation, democracies are 4.5 times as likely to adopt FIT policies as autocracies. This finding is strongly statistically significant and holds for different measures of regime type.

Our theory predicts that democratic political competition creates incentives for FIT implementation for both environmental and distributive reasons, and we expect these incentives to exist across all stripes of democracies. Level of development, corruption, status of transitional democracy, or policy diffusion do not predict FIT adoption. Consistent with accounts emphasizing distributive politics, institutional "malapportionment" (Samuels and Snyder, 2001; Broz and Maliniak, 2011) in favor of rural political constituencies encourages FIT adoption. This finding suggests that FITs are attractive to gov- 
ernments because they generate both environmental public goods for the mass public and concentrated benefits for politically influential rural constituencies.

Because our theory departs from available works by emphasizing the exact type of environmental policy, an important contribution of this article is to explain why the specific design features of the FIT make it so popular among democracies. If we are wrong about the importance of not only environmental merit, but also distributional concerns, then democracies should also implement policies that fail to produce the FIT's distributional effects. Perhaps the most important of such policies is the renewable portfolio standard (RPS). This policy does not offer new entrants to enter the power generation market. It simply requires that existing utilities generate some of their power using renewable energy. This policy does not benefit players other than the already powerful incumbents in energy markets. A data analysis of RPS adoption shows that there is little difference between autocracies and democracies, highlighting the importance of considering the specific type of environmental policy. The same is true of another new popular policy instrument, tendering of renewable energy contracts to private bidders. Democracies do not favor all environmental policies; instead, they choose those policy types which generate large environmental gains, electoral benefits, and political support to the incumbent government. While we cannot fully distinguish between the relative importance of these factors with the available data, our finding underscores the importance of distinguishing between different types of policy instruments.

We contribute to several canonical bodies of literature in political science. First, by showing that the political incentives created by democracy apply to renewable energy, we contribute to the growing literature that emphasizes political accountability and competition as the core components of democracy (Przeworski, 1991; Wittman, 1995; Lake and Baum, 2001; Adserà, Boix, and Payne, 2003). Second, we show that democracy is associated with specific types of policy instruments, consistent with the idea that policy design is critical from a distributive perspective (Buchanan and Tullock, 1975; Campos, 1989; Keohane, Revesz, and Stavins, 1998), instead of a general increase in environmental policy stringency. Finally, we offer insights into the development of renewable energy policy. While the issue has been studied extensively in previous works (Lipp, 2007; Mendonça, 2007; Aklin and 
Urpelainen, 2013), ours is the first political analysis of a potent political instrument on a global scale. We show that distributional concerns play a major role in explaining renewable energy, with important implications for the political economy of environmental policy more generally (Neumayer, 2003).

\section{Explaining FIT adoption: Theory and hypotheses}

How can we explain the rapid global spread of the FIT despite its economic cost and the strength of traditional energy interests that stand to lose from it? To explain the rapid adoption of the FIT by so many countries that initially seemed unlikely candidates for ambitious renewable energy policy, we propose that democratic political competition is the primary determinant of renewable energy policies that offer distributed gains to mass constituencies, such as the FIT. Among democracies, in turn, FITs are particularly attractive if political institutions put disproportionate weight on the votes of rural constituencies due to malapportionment.

\section{Democracy and feed-in tariffs}

By a feed-in tariff, we refer to a policy that mandates energy utilities to pay a premium to producers that generate electricity from renewable sources (Mendonça, 2007). For example, the German Stromeinspeisungsgesetz (StromEinspG) of 1990 guaranteed grid access to third parties and offered a percentage premium for sources such as wind and solar. In the case of Tanzania, rates were differentiated by region and depending on whether renewable electricity comes from generators connected to the national grid or small microgrids (UNEP, 2012: 29).

The premium offered to renewable electricity is important because it encourages producers of all stripes to invest in power sources, such as wind or solar. According to the FIT literature, this policy has been exceptionally effective in promoting renewable energy (Couture and Gagnon, 2010; Mitchell, Bauknecht, and Connor, 2006; Mendonça, 2007; Smith and Urpelainen, 2014) and, perhaps most importantly, it has been behind Germany's aggressive renewable electricity growth since 1990 (Lipp, 2007). The generosity of the tariff on offer also varies, both across states and technologies. According to data on OECD countries for the years 1978-2005 (Johnstone, Haščič, and Popp, 2010), governments offered average FIT premiums across types of renewables ranging from 0.02 to 10.3 US\$ cents per 
kilowatt-hour of electricity. Critical for our analysis, FIT policies rarely exist on paper only-we reviewed FIT policies in all 60 countries with an FIT, finding evidence on actual implementation and positive effects for renewable energy generation in $95 \%$ of the cases. Generally, FIT policies are also more generous and effective in democracies than in autocracies, as one would expect if democracies value the FIT more than autocracies.

In explaining FIT adoption, we emphasize on political competition and accountability as the fundamental features of democracies. Since a large number of voters determines a government's political survival (Dahl, 1989; Wittman, 1995; Adserà, Boix, and Payne, 2003; Lake and Baum, 2001; Cheibub, Gandhi, and Vreeland, 2010; Bueno de Mesquita et al., 2003), the government has incentives to select policy instruments that appeal to these voters, instead of only catering to a narrow political elite. While democracies are also vulnerable to political failure because of special interests and other threats (Olson, 1982; Grossman and Helpman, 1994), political competition mitigates these threats at least relative to autocracies. Neither regime type is perfect for the median voter, but on average democracy is the better of the two. As detailed below, the FIT has unique features that allow governments to break the dominance of entrenched energy interests, such as the heavy industry. This explains why interest group politics do not raise insurmountable barriers to FIT adoption.

For democratic governments, the FIT is a politically expedient policy instrument. For one, as a very effective renewable energy policy, it generates environmental and economic public goods for large groups of people. Renewable energy substitutes for fuels that produce higher levels of negative externalities. In practice, renewable energy usually replaces electricity generation from coal, with large benefits in the form of reduced air pollution (Muller, Mendelsohn, and Nordhaus, 2011). Reduced air pollution carries important health and economic benefits. In a democratic system, voters reward their government for the provision of these highly visible benefits (Cao and Prakash, 2012).

Environmental benefits are not enough to explain the democratic success of the FIT, however, because many other policy instruments produce similar outcomes. Therefore, we analyze the distributive implications of the FIT. Since many forms of renewable energy such as wind power and biomass are often produced in the countryside, advocates maintain that investment in this sector is a strategy of ru- 
ral renewal. The decentralized nature of renewable electricity generation implies that the FIT premium benefits rural communities through improved employment prospects and direct profits from electricity generation. While the macroeconomic effects of the FIT and other environmental policies may or may not be positive (Bezdek, Wendlinga, and DiPerna, 2008), democratic governments value the FIT's rural benefits more than autocracies, given the "urban bias" in the latter (Bates, 1981). The FIT can be designed so that it also promotes off-grid electricity generation by paying a premium to producers who connect to a microgrid, and some countries such as Peru only offer an FIT to the off-grid segment of the market (UNEP, 2012: 29). In developing countries with deprived communities in the countryside, such promotion of energy access is particularly attractive to rural voters. Tanzania, for example, encourages off-grid generation by using the relatively high cost of operating diesel generators as the basis for the off-grid FIT rates (UNEP, 2012: 35). Therefore, even the governments of least developed democracies may expect considerable political gains from the FIT. This is the more the case for democratizing nations like Kenya, where an FIT policy was adopted in 2008 only six years after the first free elections in order to gain electoral support among rural voters who were largely overlooked at the expense of the urban elite under autocratic rule. ${ }^{2}$

Finally, the FIT itself dismantles the profit monopoly of established utilities, thus building political support for a democratic government among a large number of new power generators. The FIT premium for renewable energy is paid to anyone who enters the power sector, thereby increasing the sector's competitiveness. This disperses profits and improves the supply of power, producing benefits to the society as a whole. The benefits are not limited to a small number of established players. In the case of Denmark, agricultural cooperatives played a critical role in the early deployment of wind power and, therefore, benefited greatly from the FIT's wind electricity premium (Hvelplund, 2013). In turn, the beneficiaries became strong supporters of the government's renewable energy policy.

While democratic governments have incentives to consider the preferences of powerful and politically active energy utilities (Aidt, 1998; Stenzel and Frenzel, 2008), these incentives are, compared to autocracies, mitigated by the nature of political competition in a democratic system (Stigler, 1972;

\footnotetext{
${ }^{2}$ A more complete case study of FIT adoption in Kenya and other countries can be found in appendix A6.
} 
Lake and Baum, 2001). Democratic governments can use the FIT to overcome "regulatory capture" (Stigler, 1971) from entrenched interests by creating new energy constituencies, such as small wind and solar producers. In a Grossman and Helpman (1994) framework, this amounts to endogenously changing the balance of power among green versus other interests. The wind energy lobby, both in Germany and Denmark for example, have grown to be politically influential players (Michaelowa, 2005; Vasi, 2011). As Aklin and Urpelainen (2013) show, democratic governments benefit from strategically using renewable energy policy to create constituencies with a strong interest in the political survival of the incumbent government. Specifically, they find that governments in industrialized democracies carefully manage the creation of new constituencies to expand their support coalition. At the same time, democratic governments also reap the electoral benefits from reducing negative externalities that hurt mass constituencies, meaning that there is a double dividend available from FIT adoption.

In the language of distributive politics, FIT adoption combines two important goals. On the one hand, it provides environmental and energy public goods to the large electorate (Aidt, 1998; Lake and Baum, 2001). On the other hand, it also generates targeted benefits to influential constituencies, allowing governments to cater to their core supporters (Cox and McCubbins, 1986) or swing voters (Besley, Persson, and Sturm, 2010). By tailoring the design of the FIT, the government can use it to achieve its redistributive goals while providing public goods. The FIT allows the government to solve the problem of providing public goods to a large number of voters, while simultaneously targeting a large share of these benefits to politically powerful constituencies (Lizzeri and Persico, 2001). Below we propose that rural constituencies are ideal targets for FIT benefits, though we acknowledge that ours is not a full theory of the targeting of the FIT.

There is widespread variation in FIT design. To verify that the FIT data reflect our theoretical expectations, we created an original data set of the key design features of FIT policies across the world, the details of which can be found in the online appendix. Most importantly, many FIT policies impose size restrictions (usually preventing largest producers from gaining access) and/or differentiate tariffs based on size. Moreover, many FIT policies guarantee grid access to independent producers and, 
in developing countries with rural electrification issues, promote off-grid power generation. These observations are consistent with our argument, which emphasizes the importance of distributional consequences and the details of policy design. Indeed, democracies tend to design their policies in view of distributional politics more often than autocracies.

FIT adoption is not costless. It increases the average cost of electricity generation because utilities must pay a premium for the included energy sources. This is yet another reason why we expect a democracy-autocracy difference. Since the costs fall mostly on established energy utilities, whose political clout is maximized under institutions that prevent the masses from using their voice (Lake and Baum, 2001), their ability to resist FITs is pronounced under autocratic rule. Also important, the FIT is not a tax. While it may or may not increase the cost of electricity to the consumer, it is not an explicit tax imposed by the government that would be an easy target to the political opposition. In the United States, a 2013 survey shows that $55 \%$ of the public supports renewable energy mandates at an annual cost of US\$ 100 per year, while only $43 \%$ support a carbon tax that would be given back as a refund to every American household (Leiserowitz et al., 2013). Therefore, a democratic government may more easily enact an FIT than impose a carbon tax. Given this reasoning, we expect democracy to be a powerful predictor of FIT adoption.

Hypothesis 1 (democracy and feed-in tariffs). Compared to autocracies, democracies are more likely to adopt feed-in tariffs.

As compared to democracies, autocracies have fewer reasons to enact FITs. Not only do they value the public good of clean energy less, but they also have fewer incentives to redistribute profits from incumbent utilities to a larger group of small producers. At the same time, autocracies favor urban constituencies (Bates, 1981; Bezemer and Headey, 2008), so that the benefits of FIT adoption for rural constituencies carry less weight than under democratic political institutions. Therefore, even though democratic political institutions also have their pathologies and give plenty of access to special interests under "regulatory capture" (Stigler, 1971), the typical autocratic ruler stands to gain much less from an FIT than a democratic government.

To be sure, the democracy-autocracy difference hinges on the political salience of the FIT in demo- 
cratic countries. As Culpepper (2010) notes, special interest can prevail in democratic systems in "quiet politics," that is, when the issues fall under the radar of the public. In country case studies, we see plenty of evidence for the salience of FIT decision in electoral politics. In Germany and Denmark, FIT adoption and revision have been high-profile issues and enjoyed the support of large segments of the population (Lipp, 2007; Vasi, 2011). As Lauber and Mez (2004: 17) write, in the German case, the renewable energy advocacy coalition comprised "researchers, farmers, technicians, entrepreneurs, customers." They also emphasize the Green Party's aggressive and consistent advocacy of renewables. In the Danish case, "an advocacy coalition that initially started with a few wind enthusiasts was able to grow into a veritable influence ... local ownership helped create widespread support for [renewable energy], especially wind, because benefits were distributed across a wide group of people" (Lipp, 2007: 5486). In Spain, "the broad social and political coalition" led by "the influential Association of Small Renewable Energy Producers" organized "an intensive communication and lobbying campaign," allowing the FIT to gain popularity among the public (del Río González, 2008: 2917-2919). In Portugal, the government specifically directed some of the wind energy revenue to local communities in an effort to "improve public acceptance and cooperation between project developers, power producers and the municipalities" (IRENA/GWEC, 2012: 112).

\section{Democracy and portfolio standards}

Above, we emphasized the FIT's environmental effectiveness, its potential for contributing to rural development, and its distribution of gains to diverse constituencies. We would not expect democracy to promote renewable energy policies that fail to produce these desired distributive effects. This section further elaborates on the analytical logic by explaining why democracy should not promote the adoption of renewable portfolio standards (RPS). By an RPS, we refer to the requirement that utilities must generate a certain share of the total energy they sell from renewable sources. For example, such systems have been frequently used by different U.S. states to promote the growth of renewable electricity generation (Lyon and Yin, 2010). Sometimes called "green certificates," they are widely considered a primary alternative to FITs (Ringel, 2006; REN21, 2012).

Unlike the FIT, the RPS does not encourage renewable energy generation by new entrants. The 
mandate is focused on existing utilities, and these have no incentive to lower entry barriers for outsiders. While the FIT opens the renewable electricity market for new players, the RPS focuses on regulating the behavior of existing players without guaranteeing grid access to third parties.

For democratic governments, the RPS has two political disadvantages. First, the RPS does less to promote the growth of renewable electricity than the FIT. Since new entrants are discouraged, the level of competition in the power sector does not increase, and this means that the cost of renewable electricity remains higher than in the counterfactual case of enhanced competition. Second, the RPS does not distribute gains from power production outside the existing utilities, which mostly rely on fossil fuels and hydropower. Since the RPS does not open energy markets for third parties, it allows utilities to maintain monopolistic power and reap the associated rents. Previously active utilities, which are often large due to economies of scale, are the primary subject of the RPS. This means that a democratic government cannot expect large electoral gains from creating profitable opportunities for third parties. Hence, we do not expect democracy to promote RPS adoption. ${ }^{3}$

Hypothesis 2 (democracy and renewable portfolio standards). Democracies and autocracies are equally likely to adopt renewable portfolio standards.

\section{Variation among democracies: Rural constituencies and feed-in tariffs}

As noted above, our argument draws on distributive politics. We emphasize the FIT's ability to confer benefits to independent renewable energy producers in rural areas. This expectation can be used to sharpen our theory by identifying those democracies that are particularly inclined toward FIT adoption. To summarize, we expect a rural bias in democratic political institutions stemming from the malapportionment of votes to promote FIT adoption.

This expectation can be derived from a distributive politics approach to democracy. Even though democracies have stronger incentives to provide citizens with public goods than autocracies, among democracies the political distribution of benefits varies. Where rural voters are powerful, the government has an incentive to channel resources to them (Samuels and Snyder, 2001; Broz and Maliniak,

\footnotetext{
${ }^{3}$ In appendix A4, we use cross-sectional data on a new popular policy, the tendering of renewable energy contracts to private bidders, to show that democracy does not have any effect on these tenders, highlighting the unique virtues of the FIT.
} 
2011). Because the FIT creates profitable opportunities to small energy producers in rural areas, a bias in favor of rural constituencies should encourage governments to adopt this policy. Studies of the technical potential of renewable energy show that wind energy is not feasible in densely populated urban areas because of the land area needed (Hoogwijk, de Vries, and Turkenburg, 2004), while biomass energy naturally requires a large natural resource base not available in cities. By adopting an FIT, the government provides the public good of renewable energy to the population, while ensuring that a large proportion of the gains goes to politically influential rural constituencies. In Olson's (1965) terms, a rural population with political clout is a "privileged group" that is capable of securing gains from political resource allocation. Although the FIT is a national instrument that cannot be used to target specific electoral districts, such as those with core or swing voters, it is expedient because it generates large benefits for rural constituencies and, at the same time, provides environmental public goods to the mass public.

We do not expect large rural populations themselves to promote FIT adoption. In countries with large rural populations, the number of potential beneficiaries is large, but this feature also means that the FIT would be very costly. If FIT adoption resulted in large amounts of renewable energy generation in rural areas, the country would pay a high price in steep increases of electricity costs. Unless the rural population would exert a disproportionate political influence, the government would have to pay a high price for each rural vote, implying that the political cost and benefit of FIT adoption would increase in tandem. If, in contrast, the rural population had disproportionate political clout, the value of rural political support would be high for any given size of the rural population.

Empirically, we measure rural bias in political institutions with the "malapportionment" of votes. As Samuels and Snyder (2001) note, democratic electoral institutions of all stripes frequently overallocate legislative seats to rural constituencies. In this case, the value of one rural vote is higher than the value of one urban vote, making rural voters a primary target of competition among political parties. In a variant of this argument, Broz and Maliniak (2011) show that such malapportionment can explain variation in gasoline taxes, as rural voters would suffer from high transportation costs the most. They also provide evidence for the rural bias originating from malapportionment in the United 
States, Japan, Brazil, and Argentina (Broz and Maliniak, 2011: 9). In an empirical application of their malapportionment approach, Snyder and Samuels (2001) find that, in 19 Latin American countries, malapportionment in both lower and upper chambers creates a bias in favor of rural constituencies. In the case of FIT adoption, malapportionment may be expected to bring environmental benefits. Because rural constituencies can expect to reap benefits from renewable energy generation under the FIT, malapportionment encourages governments to adopt FITs to furnish tangible benefits to the rural population while also mitigating negative environmental externalities from fossil fuels. This dual incentive allows us to identify those democratic countries that have a particularly strong incentive to adopt the FIT.

Hypothesis 3 (democracy, malapportionment, and feed-in tariffs). Among democracies, institutional malapportionment in favor of rural constituencies is positively associated with the adoption offeed-in tariffs.

Notably, this argument also applies in the case of developing countries, though data availability prevents us from fully exploring the role of economic development in the politics of malapportionment. Notwithstanding urban bias in developing countries, both classic (Bates, 1981; Varshney, 1995) and recent studies (Bezemer and Headey, 2008; Wallace, 2013; Kim and Urpelainen, 2015) show that this bias is much more severe in autocracies than in democracies.

Subject to data availability, this hypothesis can be applied to the level of FIT tariffs as well (Johnstone, Haščič, and Popp, 2010). We do not have such data for non-OECD countries, but for industrialized states we conduct a robustness test of the hypothesis that malapportionment encourages governments to provide generous FIT support, and find support for it.

\section{Research design}

We begin by comparing FIT adoption behavior of democracies and autocracies. Because we are interested in the global patterns of FIT adoption, we analyze a data set that covers as many years and countries as possible. Our dependent variable is a binary indicator for FIT adoption. We analyze a data set comprising the years 1990 to 2012 and at most 112 countries, depending on model specification. 
The data are provided by the 2012 annual report of the REN21 policy network (REN21, 2012), but we verified the coding ourselves and report extensive robustness checks in appendices A13 and A14 for unclear cases. This widely cited report evaluates the status of the global renewable energy market and policies every year, collecting data on investment, prices, and government activity. The length of the temporal frame is determined by the enactment of the first FIT by Germany in 1990. We ignore years before that to avoid counting a large number of zeros at a time when governments were not aware of FIT policies. $^{4}$

The data have several advantages for comparative political analysis. First, it offers a global perspective. This is essential because there is limited research on renewable energy policy outside the traditional OECD countries (Schaffer and Bernauer, 2014; Neumayer, 2003). Second, the data cover the universe of FITs in existence. The authors of the report investigate the enactment of new FITs on a global scale, including even the least developed countries in their analysis.

Given a binary dependent variable, we estimate logistic regressions with standard errors clustered by country. The data set is formatted for time-series, cross-section survival analysis (Beck, Katz, and Tucker, 1998), so that country $i$ is excluded from time $t+1$ on if it adopts an FIT at time $t$. With $i$ indexing countries and $t$ indexing years, the estimation equation is specified as follows

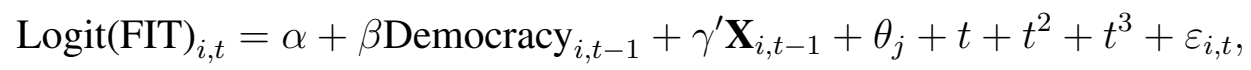

where $\mathbf{X}_{i, t-1}$ is a vector of controls, $\theta_{j}$ denotes region fixed effects for five UN regions $j$ (Africa, Americas, Asia, Europe, and Oceania), and $t, t^{2}, t^{3}$ denote linear, quadratic, and cubic time trends (Carter and Signorino, 2010). The error term is $\varepsilon_{i, t}$. Explanatory variables are lagged by one year.

We also estimate semi-parametric Cox (1972) proportional hazard models with time-varying covariates. We use Schoenfeld residuals as a global test for non-proportionality and fix violations of the proportional hazards assumption by including the logarithm of time and the interaction term of this logarithm and the offending variable into our model specifications (Box-Steffensmeier and Zorn,

\footnotetext{
${ }^{4}$ In 1978, the United States adopted the Public Utility Regulatory Policies Act, which is sometimes considered an FIT. We exclude it because the implementation was left for the states, and it did not specifically target renewable energy.
} 
2001). The regression results from this Cox model yield substantively identical results.

\section{Dependent variable: Feed-in tariff}

Our dependent variable is a binary indicator denoting whether an FIT policy was adopted in a given country-year (REN21, 2012). ${ }^{5}$ Figure 1 shows the geographic distribution of our dependent variable in 2012, and we list the year of adoption and regime type for these countries in the appendix. Since we do not have time series data on the exact level of support provided by the FIT, we cannot evaluate the stringency of policy instruments adopted by different countries. However, we verified that, with the exception of two autocracies (Algeria and the Syrian Arab Republic), there is clear evidence that FIT policies have been actually implemented even in developing countries and tariffs have benefited renewable energy projects. Even in the poorest countries in our sample, FIT policies were implemented by the governments; our results are also robust to excluding all least developed countries from the sample (Appendix A12).

[Figure 1 about here.]

\section{Placebo: Renewable portfolio standards}

The data for the RPS also come from REN21 (2012). Again, the indicator is binary, and the data is in survival format. By 2012, there are only eleven countries that have adopted RPS at the national level, though there are many subnational units such as U.S. states that have done so. Given our focus on national governments, these are not considered in the analysis.

\section{Explanatory Variables}

We use two measures of democratic regime type. The first is a binary classification based on fully free and competitive elections (Cheibub, Gandhi, and Vreeland, 2010). This simple indicator is suitable for testing our theory because it emphasizes the role of political competition and accountability as the cornerstones of democracy. The downside of this measure is that it is only available until the year 2008. While the lack of data reduces sample size, this problem is alleviated by the use of survival

\footnotetext{
${ }^{5}$ We only have data on the level of FIT support for a small sample of OECD countries and report results in appendix A11.
} 
data. All countries that adopted an FIT before 2008 are excluded from the analysis, so that missing information for regime type for all those excluded countries does not do any harm to our estimation.

As a complementary measure, we rely on the Polity IV democracy-autocracy score (Marshall, Jaggers, and Gurr, 2010). ${ }^{6}$ Ranging from -10 to +10 , it measures democracy along multiple dimensions, with a focus on competition for power and executive accountability. It is highly correlated with the Cheibub, Gandhi, and Vreeland (2010) measure $(r=+0.82)$. The major advantage of this measure is that it is available until 2011. Lagged by one year, it allows us to use all years in our data set.

Figure 2(a) shows FIT adoption for democracies and autocracies, clearly highlighting that the growth of the FIT has largely been driven by the former regime type. To normalize the adoption numbers by a baseline, Figure 2(b) shows a mosaic plot. Again, it is consistent with the democratic incentive to adopt the FIT.

[Figure 2 about here.]

\section{Control variables}

We use an extensive set of control variables to safeguard our results against omitted variable bias. Because policies diffuse across borders (Ward and Cao, 2012; Schaffer and Bernauer, 2014), we include a diffusion measure of how many neighboring countries, normalized by neighbor count, have adopted an FIT policy in order to capture potential policy spillovers. ${ }^{7}$ Perhaps it is political constraints rather than distributional concerns that make democracies more likely to adopt FIT policies. To control for this alternative explanation, we add the PolCon III political constraints variable from Henisz (2000) to all our specifications. We further include the logarithm of GDP per capita to account for the possibility that income induces the population to demand environmental policy as a luxury good (Franzen and Meyer, 2010). Wealthier countries may implement economically costly policies because their affluence leads them to emphasize environmental quality due to its effect on quality of life and wellbeing. Measured in US\$ with constant year 2000 prices, the data are from the World Development Indicators (WDI). We also add the logarithm of a country's population as well as its land area, again from the

\footnotetext{
${ }^{6}$ We code cases of foreign interruption, interregnum, and transition years as zero.

${ }^{7}$ Appendix A22 estimates spatial lag models without any change in results.
} 
WDI. Functioning renewable electricity markets depend on economies of scale, and the requisite scale is easier to achieve in a more populous country, controlling for affluence. Controlling for population, a larger land area suggests more potential for renewable energy resources, such as biomass.

Next, we use the International Country Risk Guide's standard measure of corruption to account for implementation capacity. The FIT is a complex regulatory instrument that must be carefully designed for economic cost-effectiveness and political gain. Moreover, it must be enforced because energy utilities prefer not to pay the mandatory premium to electricity generators. For these reasons, corruption may undermine the implementation of the FIT. At the same time, it is important to distinguish between political accountability through electoral competition and corruption, as our theory emphasizes the former at the expense of the latter. The value of the variable ranges from 0 to 6 , with higher values indicating more corruption.

In addition to these covariates, some models include variables on the energy sector. First, we add the logarithm of a country's carbon dioxide emissions per capita from the WDI. Countries that produce large amounts of carbon dioxide may use the FIT to mitigate climate change (Lipp, 2007). Similarly, we include a country's share of fossil fuels in total energy consumption. Countries that rely heavily on fossil fuels may want to reduce their dependence by implementing an FIT, given that renewable electricity directly competes with coal. Third, we include the logarithm of total electricity generation, measured in billions of kilowatt hours. The data are from the United States Energy Information Administration. Since the FIT is particularly suited for the electricity sector, this variable complements population to capture possible scale effects. Since large electricity markets create more opportunities for independent power generators, they may be more conducive to the growth of renewable energy through FIT adoption. Fourth, we also control for power sector reform with data from Erdogdu (2011), which measures how many reform steps (0-8) a country has implemented on its way to electricity market liberalization. ${ }^{8}$ Since FIT policies introduce competition among power producers, incentives to adopt these policies should be higher in countries with advanced levels of electricity market liberalization.

\footnotetext{
${ }^{8}$ This data cover years 1982 to 2008 . To avoid losing the last four years in our sample, we carry 2008 values forward to 2012 .
} 
A final set of variables captures international influences. We include the sum of exports and imports relative to total GDP to account for trade openness. The variable is logarithmized to normalize the distribution. Similarly, we include net inflows of foreign direct investment. These variables, both from the WDI, capture the possibility that trade and investment competition discourage countries from adopting environmental policies. Another channel of international influence may come in the form of official commitments in the Kyoto Protocol to reduce carbon emissions, thereby promoting the use of renewables, for instance, through FITs. We thus control for Kyoto Protocol ratification. Finally, we include an OECD membership indicator to account for status as an industrialized country and an EU membership indicator because European countries have sought leadership in climate policy (Schreurs and Tiberghien, 2007).

\section{Results}

This section presents five sets of results: First, we discuss the main results and several robustness checks for our global sample of FIT adoption. Second, we leverage case study evidence to highlight how policy design speaks to our distributional argument, before reporting results from our placebo test for RPS adoption. Next, we explore the malapportionment variation among democracies. We end this section by showing that FIT policies in developing countries are not shallow and are much more than only symbolic politics.

\section{Democracy, autocracy, and the feed-in tariff}

The results from the FIT logistic regressions are reported in Table 1. Models (1)-(3) report coefficients for the binary democracy measure, while models (4)-(6) replace it with the Polity IV score. Other than this, only the choice of control variables varies. All models include dummies for OECD status, EU membership, region fixed effects, and three orders of time trends.

[Table 1 about here.]

The results show that democracy is strongly associated with FIT adoption. The coefficient is statistically significant at least at the $p<0.05$ level in all six models and stable across estimations, with 
two different democracy measures. This itself is remarkable, given that the number of observations and control variables varies significantly across models.

Based on models (3) and (6), we simulate substantive effects for democracy from 1,000 draws from a multivariate normal distribution, while holding continuous variables at their means and discrete variables at their median values (King, Tomz, and Wittenberg, 2000). For both Cheibub, Gandhi, and Vreeland's (2010) democracy variable and Polity IV scores, we find substantively large and strongly statistically significant effects on FIT adoption. For a one unit change in the Cheibub, Gandhi, and Vreeland (2010) democracy variable-from autocracy to democracy-democracies are on average about 4.5 times as likely to adopt an FIT when compared to their autocratic counterparts, with 1.2 and 12.1 as the lower and upper bounds of the $95 \%$ confidence interval. While the effect of a shift of the Polity IV score along its interquartile range is smaller than for the Cheibub, Gandhi, and Vreeland (2010) measure, democracies still have a 3.3 times higher likelihood of FIT adoption; the confidence interval ranges from 1.1 to 9.4.

Other explanatory variables are less powerful. In our most comprehensive model specification, the only other two variables that are statistically significant and consistently signed across models are power sector reform and trade openness. As expected, countries with more liberalized electricity markets are more likely to adopt FIT policies, while more open economies are more hesitant to do so, potentially because they are fearful to lose competitive advantages (Bechtel and Tosun, 2009). To put effect sizes into perspective, we find that we need to move our power sector reform variable from its lowest value to the $80 \%$ percentile in order to achieve an increase in the probability ratio to adopt an FIT that is about equivalent to a change from autocracy to democracy. This means essentially going from a completely state-controlled electricity market to almost full liberalization, with complete unbundling, establishment of a regulatory agency, and privatization of generation, transmission, and distribution. Similarly, decreasing a country's trade openness from where its sum of exports and imports are 1.5 times its GDP (e.g., Bahrain or the Netherlands) to where its summed exports and imports account for just about $40 \%$ of its GDP (e.g., France or the UK) increases the probability to adopt an FIT by the same magnitude as a change in the country's institutional setup would. 
These additional analyses show how small the substantive effects of any other variables are when compared to the effect of the democracy variable. As our logistic regressions correctly classify approximately $97 \%$ of the outcomes, the absence of statistically significant covariates is compatible with our theoretical idea that the strong pull of democracy overwhelms the effect of other variables, be they economic or political. Consistent with our argument, democracy is the single most important predictor of FIT adoption.

The appendix reports additional tests. ${ }^{9}$ First, we control for transmission and distribution losses, the lagged number of projects from the Clean Development Mechanism (CDM), and lagged renewable electricity generation. These variables control for a country's energy infrastructure and its attractiveness for renewable energy. In another test, we use data from the World Values Survey to control for environmental public opinion in various countries. We further exclude countries that have either dismantled or temporarily discontinued FIT policies during the period of study, and show that our main finding is not sensitive to dropping countries that implemented subnational FIT policies. Additionally, we use several other estimation techniques. We estimate a random effects model to give greater flexibility to the error structure, along with models with year fixed effects and cubic splines (Beck, Katz, and Tucker, 1998; Keele, 2008). We also verify that region-specific time dependence does not affect our findings.

In a recent article, Cao and Ward (2015) argue that regime stability is a critical factor for the provision of environmental public goods. To test for this relationship, appendix A17 reports additional models which control for regime stability, coded from the Polity IV data (Marshall, Jaggers, and Gurr, 2010), allowing for an interaction with our main democracy variables. While our main results remain robust, we do not find interactive effects with system stability. FIT policies, as our case studies demonstrate, are policies with potentially immediate electorate effects, whereas Cao and Ward (2015) study air pollution policies with longer lead times between decision-making and actual implementation. Regime stability may hence be more critical for policies of the latter type and be of less concern for our distributive politics argument.

\footnotetext{
${ }^{9}$ See sections A16, A18, A23, A19, A20, and A21 in the online appendix for the respective tests.
} 


\section{Case Study Lessons}

The appendix offers case studies on Kenya, Mauritius, Peru, Thailand, Germany, Spain, and Portugal. These cases show how democratic governments in both developing and developed countries have used FIT policies to pursue their socio-economic and environmental goals, while being acutely sensitive to distributional concerns. The cases highlight three important patterns: First, FIT policies are usually targeted to promote small-scale generation, thereby expanding the number of the FIT policy's direct beneficiaries and limiting the influence of powerful large electricity utilities. Second, FIT schemes in developing countries tend to have special provisions for enhanced power access in off-grid regions, thus addressing concerns of electricity poverty, whereas there is no such need in industrialized countries. Finally, FIT policies are generally effective and result in additional investments in renewable energy both in industrialized and developing countries. These findings are consistent with our theoretical expectations. Besides these democratic country cases, we also examine one autocratic FIT adopter, Algeria, finding that the rationale for FIT adoption appears to have been supply diversification and that the policy has not been effective so far.

\section{Placebo: Renewable portfolio standards}

Having demonstrated the relationship between democracy and FIT adoption, it remains to explore if RPS adoption is also strongly predicted by democratic regime type. Appendix A3 replicates the main models from above for the RPS as a dependent variable. ${ }^{10}$ There is no evidence for an effect of democracy. In contrast, other explanatory variables exert powerful influence. Total electricity generation has positive and statistically significant coefficients. Countries with large electricity markets may be in a better position to benefit from an RPS due to economies of scale, and the RPS may be less harmful to competitiveness because it does not directly increase electricity prices, provided that the state supports renewable energy generation by the utilities subjected to the policy. Other than that, the EU dummy is positive and statistically significant, mostly due to the early adoption of RPS policies in Italy (1999), the UK (2002), and Sweden (2003).

\footnotetext{
${ }^{10}$ Because of much lower RPS adoption rates, problems of model convergence require us to drop region fixed effects in these models.
} 
A new popular renewable energy policy is the auctioning of renewable energy contracts. As timeseries data for this policy is not available, we use cross-sectional data for the year 2013 from REN21's "Renewables Interactive Map" website and show that democracy has no effect on the adoption of this policy. If anything, some models indicate a negative effect. This is consistent with our expectations, as the tendering of contracts does not produce the desired distributional effects of the FIT. With tendering, contracts benefit large, existing utilities that are able to implement projects on a large scale.

\section{Malapportionment}

To test our third hypothesis, we now evaluate the role of malapportionment among democracies. In addition to all control variables above, we include four new ones. First, capturing whether a country's electoral system gives disproportionate weight to rural constituencies, we add a measure for malapportionment. Based on data by Samuels and Snyder (2001), we follow Broz and Maliniak (2011: 18) in averaging malapportionment across lower and upper chambers whenever upper chambers exist and are effective (Tsebelis and Money, 1997) to obtain an "overall level of malapportionment in a political system." For this variable, we have cross-national variation for 24 OECD and 50 non-OECD democracies in our sample, but unfortunately no time series for any given country.

Additional control variables are included to see if there are other salient factors that could explain variation among democracies. For one, we create two variables to capture democratic transition. One is based on Cheibub, Gandhi, and Vreeland's (2010) binary democracy score, the other on Polity IV scores. For the first one, we code a dummy variable that takes on the value 1 during the first five years after Cheibub, Gandhi, and Vreeland's (2010) democracy coding changes from autocratic to democratic. To show the robustness of our findings and following Marshall, Jaggers, and Gurr (2010), we code another democratization dummy variable to be 1 if a country's Polity IV score changes from 5 or less in $t-5$ to 6 or larger in year $t$. We also create a binary indicator coded 1 for each countryyear when a left-wing government is in power. Previous studies suggest that, in democratic countries, left-wing governments are often more favorable to environmental policy (Neumayer, 2003; Aklin and Urpelainen, 2013). The data come from the World Bank's Database of Political Institutions and allow us to test the effect of party ideology on FIT adoption. 
We estimate again logistic regression models with region fixed effects, OECD and EU dummies, cubic time polynomials, and country clustered standard errors. All models contain the key explanatory variables to test our above described hypothesis and are different only in terms of the included control variables. Table 2 presents the results. Malapportionment has a strong and consistently positive impact on FIT adoption among democratic countries. For five of six models, the estimated coefficient is statistically significant; even in the last model, the standard error is relatively small, with a $p$-value of 0.10. The coefficient size is large across all models. Again, using model (3) for simulating substantive effects, a change in the interquartile range for our malapportionment measure makes FIT adoption on average 2.7 times more likely (with 1.0 and 15.4 as lower and upper bounds of the $95 \%$ confidence interval). Interestingly, none of the control variables predicts FIT adoption consistently across all model specifications.

[Table 2 about here.]

In the appendix, we evaluate the relationship between malapportionment and levels of FIT support in industrialized countries. Johnstone, Haščič, and Popp (2010) provide data for FIT premiums for OECD countries up to 2005 . While there is no democracy-autocracy variation among OECD countries, malapportionment varies considerably. As our analysis in appendix A11 shows, there is a strong association between the degree of malapportionment and FIT levels $(r=0.487 ; p<0.034)$. The only clear exception to this pattern is Portugal, a country that we specifically analyze in one of our case studies. At the same time, regressions with country and/or year fixed effects testify to the irrelevance of partisanship. Neither the left-right balance of the governing coalition nor green parties affect FIT levels in a statistically significant way. Both stylized facts are consistent with our distributive argument, which emphasizes institutions at the expense of partisan politics.

\section{Are feed-in tariffs shallow in developing countries?}

An important feature of our study is the inclusion of developing countries. While most FIT research focuses on industrialized countries, we have a global data set. However, one concern about this approach is the possibility that some countries fail to implement the policy. Developing countries may 
enact de jure policies to enhance their international reputation, yet fail to implement said policies in practice. In this case, it would not be possible to compare FIT policies in industrialized and developing countries. To deal with this issue, we went through every developing country in our sample and evaluated the implementation of the FIT (Appendix A12). In only three countries-Algeria, Nicaragua, and the Syrian Arab Republic_-we were unable to find evidence of actual implementation of the policy. Of these three, only Nicaragua is a democracy. The evidence is clear, as even the poorest countries implement their FITs. We also conducted two statistical tests. First, we re-estimated our main models while excluding Algeria, Nicaragua, and Syria. Second, we re-estimated the models without any least developed, low income countries, as classified by the World Bank. Our results do not change.

\section{Conclusion}

Renewable energy is a rare bright spot in today's climate policy landscape. Here, we have sought to explain this trend. Since the FIT creates environmental public goods, enhances rural development, and distributes value to a large number of independent power producers, it is a particularly expedient policy instrument for democratic governments whose political survival depends on appealing to mass constituencies. To test this distributive explanation for the FIT, we analyzed data for up to 112 countries during the years 1990-2012. We found strong support for the effect of democratic political institutions on FIT adoption, with democracies being 4.5 times as likely to adopt the FIT as autocracies. Among democracies, institutional malapportionment in favor of rural constituencies is conducive to the adoption of FITs. In contrast, democratic countries are not more likely to adopt renewable portfolio standards or organize tenders for renewable energy auctions. These findings highlight the importance of policy design.

Our findings contribute to the study of democratic institutions and renewable energy. Scholars have increasingly emphasized the importance of renewables in weaning countries off fossil fuels (Lipp, 2007), but to date there is little evidence on why countries adopt key policy instruments. Of these instruments, the FIT has the most impressive track record (Mendonça, 2007; Smith and Urpelainen, 2014). The incentives created by democratic political competition, often emphasized by scholars of 
comparative political institutions (Przeworski, 1991; Wittman, 1995; Lake and Baum, 2001; Adserà, Boix, and Payne, 2003), are essential for understanding the global patterns of FIT adoption over the last two decades. Most scholarship on environmental and energy policy considers the effect of regime type on policy level, but ignores the equally important question of policy type. Future studies should reconsider the relationship between regime type and environmental policy by adopting more nuanced distinctions between different policy types, building on the political economy literature (Buchanan and Tullock, 1975; Campos, 1989; Keohane, Revesz, and Stavins, 1998) and our findings.

Many countries now have enacted multiple renewable energy policies (REN21, 2012), with complex interactive effects that politicians have to consider. The analysis of such interactive effects is both important for understanding the adoption of policy packages and insightful to political scientists interested in policy design. A natural extension of our project would be to see how previous policies adopted by democracies influence policy choice. For example, economic policies governing electricity generation, transmission, and distribution could shape the political-economic calculus of democratic governments in the field of renewable energy. At the same time, the effectiveness of the FIT in different circumstances calls for attention. Even if the FIT is typically deemed effective, its effectiveness may depend on the socio-economic environment. FIT effectiveness in different circumstances is not only important for policy formulation, but also sheds further light on why politicians enact this policy. Another useful extension of our study would, therefore, focus on the conditional effects of FIT enactment in different types of countries. It is certainly interesting that we found strong evidence that even the least developed countries implement FIT policies vigorously. This finding calls into question the conventional wisdom (Bechtel and Tosun, 2009; Baccini and Urpelainen, 2014) that developing countries are often opportunistic and uncommitted to the environmental policies in their books. 


\section{Acknowledgements}

We thank Joseph Brown for his assistance with data collection and seminar audiences at the Government Centre for Economic Research of Finland and the Yale School of Forestry \& Environmental Studies for useful comments on a previous version. We also thank Michaël Aklin, Thomas Bernauer, Andrew Cheon, Llewelyn Hughes, Michael G. Smith, Sung Eun Kim, and Joonseok Yang for insightful comments on previous drafts. Catalina Angel provided excellent research assistance. This research was conducted while Patrick Bayer was postdoctoral fellow in the Department of Political Science at Washington University in St. Louis and he wishes to gratefully acknowledge the hospitality of colleagues and staff. Replication materials are also available from the corresponding author's website at http://patrickbayer.com/publications/. 


\section{References}

Acemoglu, Daron, and James A. Robinson. 2001. "A Theory of Political Transitions." American Economic Review 91 (4): 938-963.

Adserà, Alicia, Carles Boix, and Mark Payne. 2003. "Are You Being Served? Political Accountability and Quality of Government." Journal of Law, Economics, and Organization 19 (2): 445-490.

Aidt, Toke S. 1998. "Political Internalization of Economic Externalities and Environmental Policy." Journal of Public Economics 69 (1): 1-16.

Aklin, Michaël, and Johannes Urpelainen. 2013. "Political Competition, Path Dependence, and the Strategy of Sustainable Energy Transitions.” American Journal of Political Science 57 (3): 643-658.

Baccini, Leonardo, and Johannes Urpelainen. 2014. "Before Ratification: Understanding the Timing of International Treaty Effects on Domestic Policies.” International Studies Quarterly 58 (1): 2943.

Bates, Robert H. 1981. Markets and States in Africa: The Political Basis of Agricultural Policies. Berkeley: University of California Press.

Bechtel, Michael M., and Jale Tosun. 2009. "Changing Economic Openness for Environmental Policy Convergence: When Can Trade Agreements Induce Convergence of Environmental Regulation?" International Studies Quarterly 53 (4): 931-953.

Beck, Nathaniel, Jonathan N. Katz, and Richard Tucker. 1998. “Taking Time Seriously: Time-SeriesCross-Section Analysis with a Binary Dependent Variable." American Journal of Political Science 42 (4): 1260-1288.

Besley, Timothy, Torsten Persson, and Daniel M. Sturm. 2010. "Political Competition, Policy and Growth: Theory and Evidence from the US.” Review of Economic Studies 77 (4): 1329-1352. 
Bezdek, Roger H., Robert M. Wendlinga, and Paula DiPerna. 2008. "Environmental Protection, the Economy, and Jobs: National and Regional Analyses." Journal of Environmental Management 86 (1): 63-79.

Bezemer, Dirk, and Derek Headey. 2008. “Agriculture, Development, and Urban Bias.” World Development 36 (8): 1342-1364.

Boix, Carles. 2003. Democracy and Redistribution. New York: Cambridge University Press.

Box-Steffensmeier, Janet M., and Christopher J. W. Zorn. 2001. "Duration Models and Proportional Hazards in Political Science.” American Journal of Political Science 45 (4): 972-988.

Broz, J. Lawrence, and Daniel Maliniak. 2011. "Malapportionment, Gasoline Taxes, and Climate Change.” Working Paper, University of California, San Diego.

Buchanan, James M., and Gordon Tullock. 1975. "Polluters' Profits and Political Response: Direct Controls versus Taxes.” American Economic Review 65 (1): 139-147.

Bueno de Mesquita, Bruce, Alastair Smith, Randolph M. Siverson, and James D. Morrow. 2003. The Logic of Political Survival. Cambridge: MIT Press.

Campos, Jose E.L. 1989. "Legislative Institutions, Lobbying, and the Endogenous Choice of Regulatory Instruments: A Political Economy Approach to Instrument Choice.” Journal of Law, Economics, and Organization 5 (2): 333-353.

Cao, Xun, and Aseem Prakash. 2012. “Trade Competition and Environmental Regulations: Domestic Political Constraints and Issue Visibility.” Journal of Politics 74 (1): 66-82.

Cao, Xun, and Hugh Ward. 2015. "Winning Coalition Size, State Capacity, and Time Horizon: An Application of Modified Selectorate Theory to Environmental Public Good Provision.” International Studies Quarterly 59 (2): 264-279.

Carter, David, B., and Curtis S. Signorino. 2010. "Back to the Future: Modeling Time Dependence in Binary Data.” Political Analysis 18 (3): 271-292. 
Cheibub, José Antonio, Jennifer Gandhi, and James Raymond Vreeland. 2010. "Democracy and Dictatorship Revisited.” Public Choice 143 (1-2): 67-101.

Congleton, Roger D. 1992. "Political Institutions and Pollution Control." Review of Economics and Statistics 74 (3): 412-421.

Couture, Toby, and Yves Gagnon. 2010. “An Analysis of Feed-In Tariff Remuneration Models: Implications for Renewable Energy Investment.” Energy Policy 38 (2): 955-965.

Cox, David R. 1972. "Regression Models and Life-Tables." Journal of the Royal Statistical Society 34 (2): 187-220.

Cox, Gary W., and Mathew D. McCubbins. 1986. "Electoral Politics as a Redistributive Game." Journal of Politics 48 (2): 370-389.

Culpepper, Pepper D. 2010. Quiet Politics and Business Power: Corporate Control in Europe and Japan. New York: Cambridge University Press.

Dahl, Robert A. 1989. Democracy and Its Critics. New Haven: Yale University Press.

del Río González, Pablo. 2008. "Ten Years of Renewable Electricity Policies in Spain: An Analysis of Successive Feed-In Tariff Reforms.” Energy Policy 36 (8): 2917-2929.

Erdogdu, Erkan. 2011. "What Happened to Efficiency in Electricity Industry after Reforms?” Energy Policy 39 (10): 6551-6560.

Franzen, Axel, and Reto Meyer. 2010. "Environmental Attitudes in Cross-National Perspective: A Multilevel Analysis of the ISSP 1993 and 2000.” European Sociological Review 26 (2): 219-234.

Grossman, Gene M., and Elhanan Helpman. 1994. "Protection for Sale." American Economic Review 84 (4): $833-850$.

Henisz, Witold J. 2000. “The Institutional Environment for Economic Growth.” Economics and Politics 12 (1): 1-31. 
Hoogwijk, Monique, Bert de Vries, and Wim Turkenburg. 2004. "Assessment of the Global and Regional Geographical, Technical and Economic Potential of Onshore Wind Energy." Energy Economics 26 (5): 889-919.

Hvelplund, Frede. 2013. "Innovative Democracy, Political Economy, and the Transition to Renewable Energy: A Full-Scale Experiment in Denmark 1976-2013.” Environmental Research, Engineering and Management 66 (4): 5-21.

IRENA/GWEC. 2012. 30 Years of Policies for Wind Energy: Lessons from 12 Wind Energy Markets. Abu Dhabi: International Renewable Energy Agency and Global Wind Energy Council.

Johnstone, Nick, Ivan Haščič, and David Popp. 2010. "Renewable Energy Policies and Technological Innovation: Evidence Based on Patent Counts." Environmental and Resource Economics 45 (1): $133-155$.

Keele, Luke John. 2008. Semiparametric Regression for the Social Sciences. Chichester: Wiley.

Keohane, Nathaniel O., Richard L. Revesz, and Robert N. Stavins. 1998. "The Choice of Regulatory Instruments in Environmental Policy." Harvard Environmental Law Review 22 (2): 313-367.

Kim, Sung Eun, and Johannes Urpelainen. 2015. "Democracy, Autocracy and the Urban Bias: Evidence from Petroleum Subsidies.” Political Studies DOI: 10.1111/1467-9248.12200.

King, Gary, Michael Tomz, and Jason Wittenberg. 2000. "Making the Most of Statistical Analyses: Improving Interpretation and Presentation.” American Journal of Political Science 44 (2): 347-361.

Lake, David A., and Matthew A. Baum. 2001. “The Invisible Hand of Democracy: Political Control and the Provision of Public Services." Comparative Political Studies 34 (6): 587-621.

Lauber, Volkmar, and Lutz Mez. 2004. "Three Decades of Renewable Electricity Policies in Germany." Energy and Environment 15 (4): 599-623. 
Leiserowitz, Anthony, Edward Maibach, Connie Roser-Renouf, Geoff Feinberg, Jennifer Marlon, and Peter Howe. 2013. "Public Support for Climate and Energy Policies in April 2013.” Yale University and George Mason University, Project on Climate Change Communication.

Li, Quan, and Rafael Reuveny. 2006. “Democracy and Environmental Degradation.” International Studies Quarterly 50 (4): 935-956.

Lipp, Judith. 2007. "Lessons for Effective Renewable Electricity Policy from Denmark, Germany and the United Kingdom.” Energy Policy 35 (11): 5481-5495.

Lizzeri, Alessandro, and Nicola Persico. 2001. "The Provision of Public Goods under Alternative Electoral Incentives.” American Economic Review 91 (1): 225-239.

Lyon, Thomas P., and Haitao Yin. 2010. "Why Do States Adopt Renewable Portfolio Standards?: An Empirical Investigation.” Energy Journal 31 (3): 131-155.

Marshall, Monty, Keith Jaggers, and Robert Ted Gurr. 2010. Polity IV Project: Dataset User's Manual. Vienna: Center for Systematic Peace.

Meltzer, Allan H., and Scott F. Richard. 1981. "A Rational Theory of the Size of Government.” Journal of Political Economy 89 (5): 914-927.

Mendonça, Miguel. 2007. Feed-In Tariffs: Accelerating the Deployment of Renewable Energy. London: Earthscan.

Michaelowa, Axel. 2005. “The German Wind Energy Lobby: How to Promote Costly Technological Change Successfully.” European Environment 15 (3): 192-199.

Midlarsky, Manus I. 1998. "Democracy and the Environment: An Empirical Assessment." Journal of Peace Research 35 (3): 341-361.

Mitchell, C., D. Bauknecht, and P.M. Connor. 2006. "Effectiveness Through Risk Reduction: A Comparison of the Renewable Obligation in England and Wales and the Feed-In System in Germany." Energy Policy 34 (3): 297-305. 
Muller, Nicholas Z., Robert Mendelsohn, and William Nordhaus. 2011. "Environmental Accounting for Pollution in the United States Economy." American Economic Review 101 (5): 1649-1675.

Neumayer, Eric. 2002. “Do Democracies Exhibit Stronger International Environmental Commitment? A Cross-Country Analysis.” Journal of Peace Research 39 (2): 139-164.

Neumayer, Eric. 2003. "Are Left-Wing Party Strength and Corporatism Good for the Environment? Evidence from Panel Analysis of Air Pollution in OECD Countries.” Ecological Economics 45 (2): $203-220$.

Olson, Mancur. 1965. The Logic of Collective Action: Public Goods and the Theory of Groups. Cambridge: Harvard University Press.

Olson, Mancur. 1982. The Rise and Decline of Nations: Economic Growth, Stagflation, and Social Rigidities. New Haven: Yale University Press.

Payne, Rodger A. 1995. "Freedom and the Environment." Journal of Democracy 6 (3): 41-55.

Przeworski, Adam. 1991. Democracy and the Market: Political and Economic Reform in Eastern Europe and Latin America. New York: Cambridge University Press.

REN21. 2012. Renewables Global Status Report: 2012 Update. Paris: REN21 Secretariat.

Ringel, Marc. 2006. "Fostering the Use of Renewable Energies in the European Union: The Race Between Feed-In Tariffs and Green Certificates.” Renewable Energy 31 (1): 1-17.

Samuels, David, and Richard Snyder. 2001. "The Value of a Vote: Malapportionment in Comparative Perspective.” British Journal of Political Science 31 (4): 651-671.

Schaffer, Lena, and Thomas Bernauer. 2014. "Explaining Government Choices for Promoting Renewable Energy.” Energy Policy 68: 15-27.

Schreurs, Miranda A., and Yves Tiberghien. 2007. "Multi-Level Reinforcement: Explaining European Union Leadership in Climate Change Mitigation." Global Environmental Politics 7 (4): 19-46. 
Smith, Michael G., and Johannes Urpelainen. 2014. "The Effect of Feed-in Tariffs on Renewable Electricity Generation: An Instrumental Variables Approach.” Environmental and Resource Economics 57 (3): 367-392.

Snyder, Richard, and David Samuels. 2001. "Devaluing the Vote in Latin America." Journal of Democracy 12 (1): 146-159.

Stenzel, Till, and Alexander Frenzel. 2008. "Regulating Technological Change: The Strategic Reactions of Utility Companies Towards Subsidy Policies in the German, Spanish and UK Electricity Markets." Energy Policy 36 (7): 2645-2657.

Stigler, George J. 1971. "The Theory of Economic Regulation.” Bell Journal of Economics and Management Science 2: 3-21.

Stigler, George J. 1972. "Economic Competition and Political Competition.” Public Choice 13 (1): 91-106.

Tsebelis, George, and Jeannette Money. 1997. Bicameralism. Cambridge: Cambridge University Press.

UNEP. 2012. Feed-In Tariffs as a Policy Instrument for Promoting Renewable Energies in and Green Economies in Developing Countries. Nairobi: United Nations Environment Programme.

Varshney, Ashutosh. 1995. Democracy, Development, and the Countryside: Urban-Rural Struggles in India. New York: Cambridge University Press.

Vasagar, Jeevan. 2013. “German Farmers Reap Benefits of Harvesting Renewable Energy.” Financial Times, December 2, 2013.

Vasi, Ion Bogdan. 2011. Winds of Change: The Environmental Movement and the Global Development of the Wind Energy Industry. New York: Oxford University Press.

Wallace, Jeremy. 2013. “Cities, Redistribution, and Authoritarian Regime Survival.” Journal of Politics 75 (3): 632-645. 
Ward, Hugh. 2008. “Liberal Democracy and Sustainability.” Environmental Politics 17 (3): 386-409.

Ward, Hugh, and Xun Cao. 2012. "Domestic and International Influences on Green Taxation.” Comparative Political Studies 45 (9): 1075-1103.

Wittman, Donald A. 1995. The Myth of Democratic Failure: Why Political Institutions are Efficient. Chicago: University of Chicago Press. 


\section{Biographical statements}

Patrick Bayer is a Lecturer in International Relations at the University of Glasgow, Glasgow G12 8RT, Scotland, United Kingdom.

Johannes Urpelainen is an Associate Professor at Columbia University, New York, NY 10027, United States of America. 


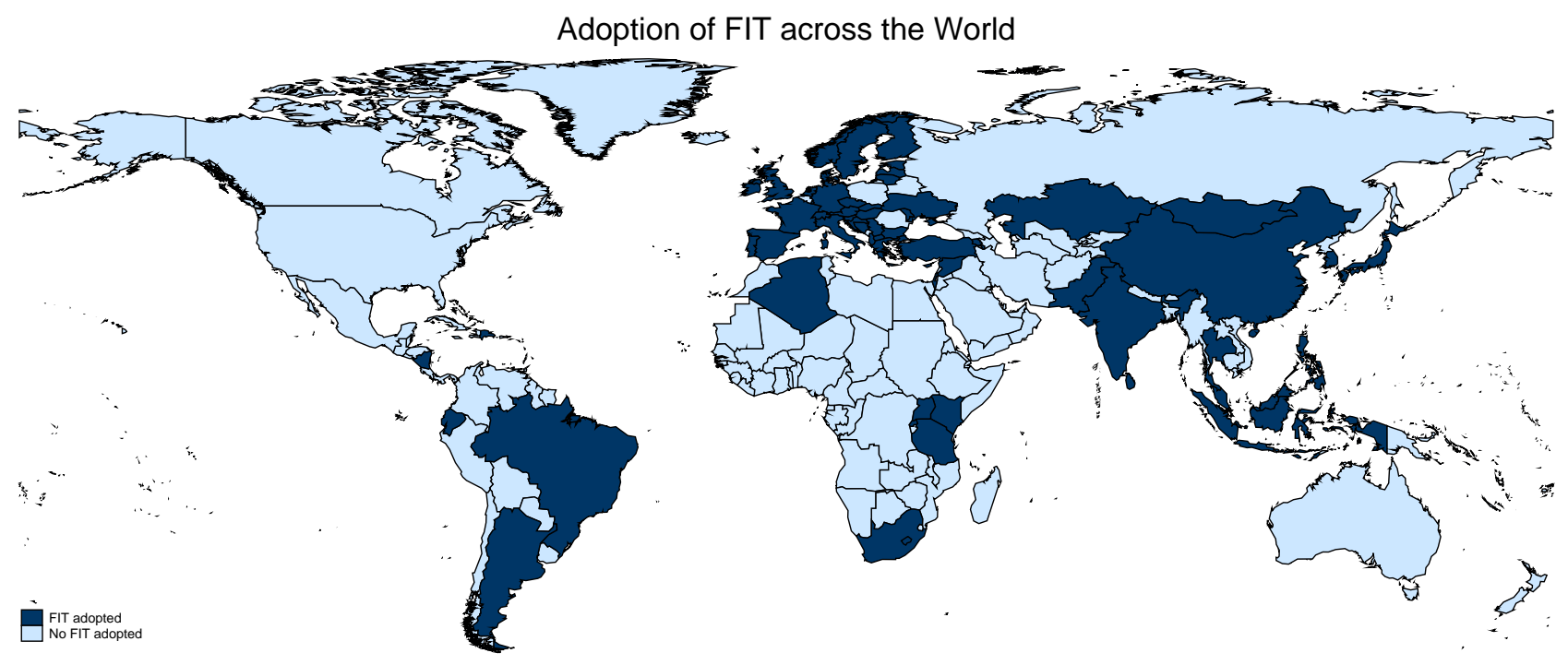

Figure 1: Worldwide adoption of FIT policies by 2012. Countries colored in dark blue have adopted an FIT policy. Of these, Brazil, South Africa, and South Korea have discontinued the policy by the end of 2012 (REN21, 2012: 118). Moreover, both Denmark and Italy changed their policies around 2002-2003. 


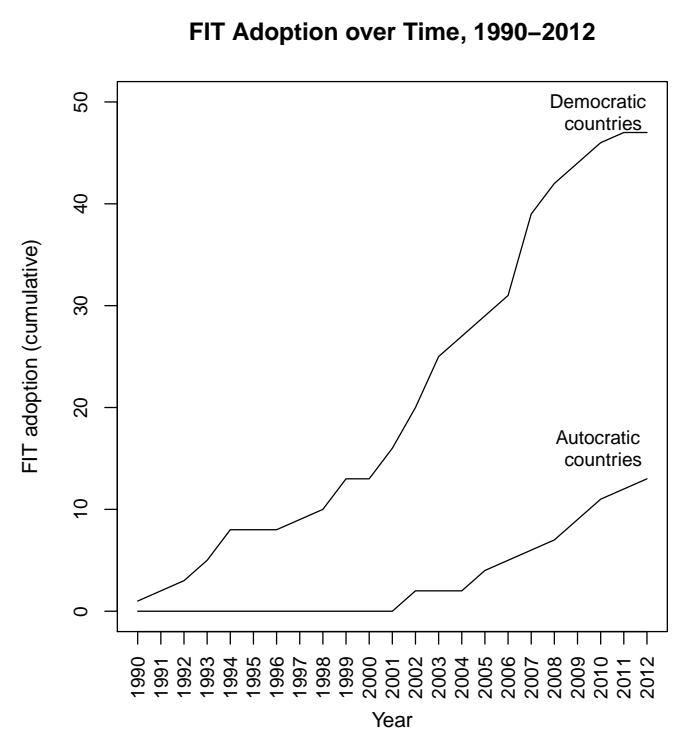

(a) Adoption of FIT policies over time, 1990-2012.

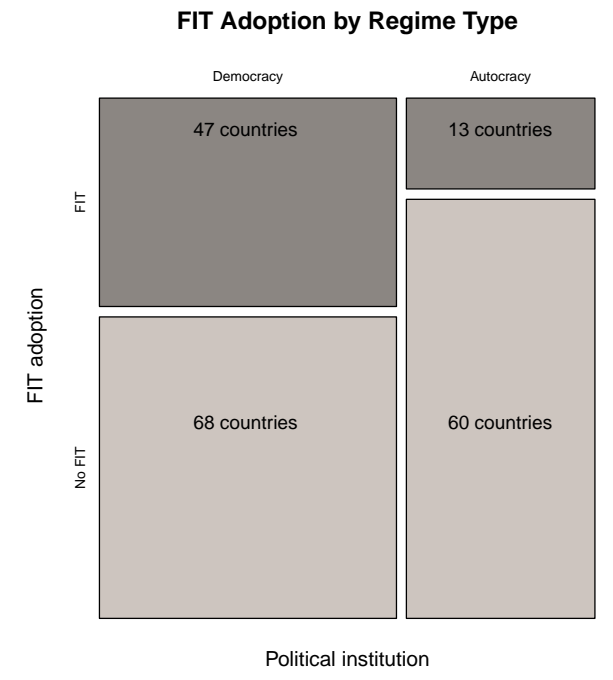

(b) Mosaic plot for FIT adoption and regime type.

Figure 2: FIT adoption over time and by regime type. 
Democracy and FIT adoption, 1990-2012

\begin{tabular}{|c|c|c|c|c|c|c|}
\hline & $\begin{array}{c}(1) \\
\text { Model }\end{array}$ & $\begin{array}{c}(2) \\
\text { Model }\end{array}$ & $\begin{array}{c}(3) \\
\text { Model }\end{array}$ & $\begin{array}{c}(4) \\
\text { Model }\end{array}$ & $\begin{array}{c}(5) \\
\text { Model }\end{array}$ & $\begin{array}{c}(6) \\
\text { Model }\end{array}$ \\
\hline Democracy dummy (t-1) & $\begin{array}{c}2.05^{* * *} \\
(0.57)\end{array}$ & $\begin{array}{c}1.90^{* * *} \\
(0.62)\end{array}$ & $\begin{array}{l}1.50^{* *} \\
(0.62)\end{array}$ & & & \\
\hline Polity IV (t-1) & & & & $\begin{array}{c}0.16^{* * *} \\
(0.05)\end{array}$ & $\begin{array}{c}0.14^{* *} \\
(0.06)\end{array}$ & $\begin{array}{c}0.12^{* *} \\
(0.06)\end{array}$ \\
\hline FIT diffusion (t-1) & $\begin{array}{l}-0.18 \\
(0.88)\end{array}$ & $\begin{array}{l}-0.16 \\
(0.96)\end{array}$ & $\begin{array}{c}-0.08 \\
(1.09)\end{array}$ & $\begin{array}{c}0.05 \\
(0.83)\end{array}$ & $\begin{array}{c}0.11 \\
(0.90)\end{array}$ & $\begin{array}{c}0.24 \\
(0.98)\end{array}$ \\
\hline Political constraints (t-1) & $\begin{array}{c}0.73 \\
(1.33)\end{array}$ & $\begin{array}{c}0.92 \\
(1.48)\end{array}$ & $\begin{array}{c}1.53 \\
(1.54)\end{array}$ & $\begin{array}{c}0.47 \\
(1.32)\end{array}$ & $\begin{array}{c}0.49 \\
(1.49)\end{array}$ & $\begin{array}{c}1.00 \\
(1.54)\end{array}$ \\
\hline GDP per capita $(\log , t-1)$ & $\begin{array}{c}0.30 \\
(0.19)\end{array}$ & $\begin{array}{c}0.58^{*} \\
(0.33)\end{array}$ & $\begin{array}{c}0.20 \\
(0.36)\end{array}$ & $\begin{array}{c}0.18 \\
(0.17)\end{array}$ & $\begin{array}{c}0.52^{*} \\
(0.31)\end{array}$ & $\begin{array}{c}0.19 \\
(0.34)\end{array}$ \\
\hline Population $(\log , \mathrm{t}-1)$ & $\begin{array}{c}0.03 \\
(0.15)\end{array}$ & $\begin{array}{l}-0.22 \\
(0.37)\end{array}$ & $\begin{array}{c}-0.44 \\
(0.36)\end{array}$ & $\begin{array}{c}0.09 \\
(0.15)\end{array}$ & $\begin{array}{c}0.06 \\
(0.33)\end{array}$ & $\begin{array}{c}-0.26 \\
(0.34)\end{array}$ \\
\hline Land area $(\log , t-1)$ & $\begin{array}{l}0.23^{*} \\
(0.14)\end{array}$ & $\begin{array}{l}0.34^{* *} \\
(0.17)\end{array}$ & $\begin{array}{c}0.12 \\
(0.17)\end{array}$ & $\begin{array}{c}0.09 \\
(0.14)\end{array}$ & $\begin{array}{c}0.21 \\
(0.16)\end{array}$ & $\begin{array}{c}0.05 \\
(0.17)\end{array}$ \\
\hline Corruption (t-1) & $\begin{array}{c}0.13 \\
(0.20)\end{array}$ & $\begin{array}{c}0.24 \\
(0.20)\end{array}$ & $\begin{array}{c}0.19 \\
(0.23)\end{array}$ & $\begin{array}{c}0.13 \\
(0.20)\end{array}$ & $\begin{array}{c}0.31 \\
(0.20)\end{array}$ & $\begin{array}{c}0.23 \\
(0.22)\end{array}$ \\
\hline $\mathrm{CO} 2$ emissions per capita $(\log , \mathrm{t}-1)$ & & $\begin{array}{l}-0.41 \\
(0.45)\end{array}$ & $\begin{array}{c}0.00 \\
(0.48)\end{array}$ & & $\begin{array}{c}-0.09 \\
(0.37)\end{array}$ & $\begin{array}{c}0.20 \\
(0.42)\end{array}$ \\
\hline Fossil fuels in energy consumption (t-1) & & $\begin{array}{l}-0.00 \\
(0.02)\end{array}$ & $\begin{array}{l}-0.01 \\
(0.02)\end{array}$ & & $\begin{array}{l}-0.02 \\
(0.02)\end{array}$ & $\begin{array}{c}-0.01 \\
(0.02)\end{array}$ \\
\hline Total electricity generation $(\log , t-1)$ & & $\begin{array}{c}0.07 \\
(0.36)\end{array}$ & $\begin{array}{c}0.18 \\
(0.34)\end{array}$ & & $\begin{array}{c}-0.15 \\
(0.31)\end{array}$ & $\begin{array}{c}0.00 \\
(0.30)\end{array}$ \\
\hline Power sector reform $(\mathrm{t}-1)$ & & $\begin{array}{c}0.21^{* *} \\
(0.08)\end{array}$ & $\begin{array}{c}0.25^{* * *} \\
(0.09)\end{array}$ & & $\begin{array}{c}0.25^{* * *} \\
(0.08)\end{array}$ & $\begin{array}{c}0.30^{* * * *} \\
(0.08)\end{array}$ \\
\hline Trade $(\log , t-1)$ & & & $\begin{array}{c}-1.29^{* *} \\
(0.53)\end{array}$ & & & $\begin{array}{c}-0.98^{* *} \\
(0.47)\end{array}$ \\
\hline FDI $(\log , t-1)$ & & & $\begin{array}{c}0.19 \\
(0.15)\end{array}$ & & & $\begin{array}{c}-0.07 \\
(0.17)\end{array}$ \\
\hline Kyoto ratification (t-1) & & & $\begin{array}{c}0.33 \\
(0.54)\end{array}$ & & & $\begin{array}{c}0.15 \\
(0.54)\end{array}$ \\
\hline Observations & 1806 & 1584 & 1429 & 1852 & 1619 & 1472 \\
\hline Countries & 112 & 104 & 103 & 111 & 103 & 102 \\
\hline Pseudo $R^{2}$ & 0.206 & 0.227 & 0.222 & 0.203 & 0.226 & 0.222 \\
\hline
\end{tabular}

Dependent Variable: FIT dummy.

Standard errors in parentheses and clustered by country.

All models include OECD and EU dummies, region fixed effects, and a cubic time polynomial.

${ }^{*} p<0.10,{ }^{* *} p<0.05,{ }^{* * *} p<0.01$

Table 1: Main results from logit model for FIT adoption. 
FIT adoption in democratic subsample

\begin{tabular}{|c|c|c|c|c|c|c|}
\hline & $\begin{array}{l}(1) \\
\text { Model }\end{array}$ & $\begin{array}{l}\text { (2) } \\
\text { Model }\end{array}$ & $\begin{array}{l}\text { (3) } \\
\text { Model }\end{array}$ & $\begin{array}{c}(4) \\
\text { Model }\end{array}$ & $\begin{array}{l}(5) \\
\text { Model }\end{array}$ & $\begin{array}{l}(6) \\
\text { Model }\end{array}$ \\
\hline Malapportionment & $\begin{array}{l}8.67^{* *} \\
(4.18)\end{array}$ & $\begin{array}{c}10.37^{* * *} \\
(4.01)\end{array}$ & $\begin{array}{c}12.29^{* * *} \\
(4.68)\end{array}$ & $\begin{array}{l}7.67^{*} \\
(4.15)\end{array}$ & $\begin{array}{l}7.43^{*} \\
(4.30)\end{array}$ & $\begin{array}{c}7.07 \\
(4.30)\end{array}$ \\
\hline Transitional democracy & $\begin{array}{c}0.29 \\
(0.91)\end{array}$ & $\begin{array}{l}-0.46 \\
(1.46)\end{array}$ & $\begin{array}{c}0.71 \\
(1.49)\end{array}$ & & & \\
\hline Transitional democracy, Polity IV & & & & $\begin{array}{l}-0.90 \\
(0.84)\end{array}$ & $\begin{array}{l}-0.93 \\
(0.94)\end{array}$ & $\begin{array}{c}-0.92 \\
(1.02)\end{array}$ \\
\hline Left government & $\begin{array}{c}0.27 \\
(0.52)\end{array}$ & $\begin{array}{c}0.19 \\
(0.54)\end{array}$ & $\begin{array}{c}0.26 \\
(0.57)\end{array}$ & $\begin{array}{c}0.22 \\
(0.51)\end{array}$ & $\begin{array}{c}0.26 \\
(0.50)\end{array}$ & $\begin{array}{c}0.30 \\
(0.50)\end{array}$ \\
\hline FIT diffusion (t-1) & $\begin{array}{c}0.55 \\
(1.07)\end{array}$ & $\begin{array}{c}0.56 \\
(1.08)\end{array}$ & $\begin{array}{c}0.25 \\
(1.20)\end{array}$ & $\begin{array}{c}0.94 \\
(1.09)\end{array}$ & $\begin{array}{c}1.07 \\
(1.08)\end{array}$ & $\begin{array}{c}1.05 \\
(1.15)\end{array}$ \\
\hline Political constraints (t-1) & $\begin{array}{l}-0.89 \\
(2.26)\end{array}$ & $\begin{array}{l}-0.94 \\
(2.50)\end{array}$ & $\begin{array}{l}-0.83 \\
(2.74)\end{array}$ & $\begin{array}{c}0.48 \\
(2.31)\end{array}$ & $\begin{array}{c}0.46 \\
(2.45)\end{array}$ & $\begin{array}{c}0.57 \\
(2.41)\end{array}$ \\
\hline GDP per capita $(\log , t-1)$ & $\begin{array}{c}0.16 \\
(0.36)\end{array}$ & $\begin{array}{c}0.69 \\
(0.56)\end{array}$ & $\begin{array}{c}0.19 \\
(0.61)\end{array}$ & $\begin{array}{c}0.33 \\
(0.33)\end{array}$ & $\begin{array}{c}0.60 \\
(0.47)\end{array}$ & $\begin{array}{c}0.19 \\
(0.51)\end{array}$ \\
\hline Population (log, $\mathrm{t}-1)$ & $\begin{array}{l}-0.54 \\
(0.38)\end{array}$ & $\begin{array}{l}-0.20 \\
(0.67)\end{array}$ & $\begin{array}{l}-0.92 \\
(0.66)\end{array}$ & $\begin{array}{l}-0.21 \\
(0.29)\end{array}$ & $\begin{array}{c}0.01 \\
(0.51)\end{array}$ & $\begin{array}{c}-0.52 \\
(0.54)\end{array}$ \\
\hline Land area $(\log , t-1)$ & $\begin{array}{c}0.16 \\
(0.24)\end{array}$ & $\begin{array}{c}0.03 \\
(0.25)\end{array}$ & $\begin{array}{l}-0.27 \\
(0.32)\end{array}$ & $\begin{array}{c}0.14 \\
(0.28)\end{array}$ & $\begin{array}{l}-0.01 \\
(0.26)\end{array}$ & $\begin{array}{l}-0.23 \\
(0.30)\end{array}$ \\
\hline Corruption (t-1) & $\begin{array}{c}0.24 \\
(0.24)\end{array}$ & $\begin{array}{c}0.26 \\
(0.26)\end{array}$ & $\begin{array}{c}0.25 \\
(0.28)\end{array}$ & $\begin{array}{c}0.32 \\
(0.25)\end{array}$ & $\begin{array}{l}0.47^{*} \\
(0.28)\end{array}$ & $\begin{array}{c}0.46 \\
(0.30)\end{array}$ \\
\hline $\mathrm{CO} 2$ emissions per capita $(\log , \mathrm{t}-1)$ & & $\begin{array}{l}-0.99 \\
(0.87)\end{array}$ & $\begin{array}{l}-1.15 \\
(1.02)\end{array}$ & & $\begin{array}{l}-0.05 \\
(0.83)\end{array}$ & $\begin{array}{c}0.09 \\
(0.84)\end{array}$ \\
\hline Fossil fuels in energy consumption (t-1) & & $\begin{array}{l}-0.02 \\
(0.02)\end{array}$ & $\begin{array}{l}-0.02 \\
(0.02)\end{array}$ & & $\begin{array}{l}-0.03 \\
(0.02)\end{array}$ & $\begin{array}{l}-0.02 \\
(0.02)\end{array}$ \\
\hline Total electricity generation $(\log , t-1)$ & & $\begin{array}{l}-0.24 \\
(0.53)\end{array}$ & $\begin{array}{c}0.10 \\
(0.51)\end{array}$ & & $\begin{array}{l}-0.14 \\
(0.42)\end{array}$ & $\begin{array}{c}0.14 \\
(0.41)\end{array}$ \\
\hline Power sector reform $(\mathrm{t}-1)$ & & $\begin{array}{c}0.08 \\
(0.10)\end{array}$ & $\begin{array}{c}0.04 \\
(0.11)\end{array}$ & & $\begin{array}{c}0.17 \\
(0.11)\end{array}$ & $\begin{array}{l}0.18^{*} \\
(0.11)\end{array}$ \\
\hline Trade $(\log , \mathrm{t}-1)$ & & & $\begin{array}{c}-2.52^{* *} \\
(1.12)\end{array}$ & & & $\begin{array}{l}-1.64 \\
(1.02)\end{array}$ \\
\hline FDI $(\log , t-1)$ & & & $\begin{array}{l}-0.06 \\
(0.27)\end{array}$ & & & $\begin{array}{l}-0.22 \\
(0.26)\end{array}$ \\
\hline Kyoto ratification (t-1) & & & $\begin{array}{c}0.21 \\
(0.99)\end{array}$ & & & $\begin{array}{l}-0.01 \\
(0.98)\end{array}$ \\
\hline Observations & 709 & 665 & 649 & 699 & 678 & 660 \\
\hline Countries & 53 & 50 & 49 & 55 & 53 & 53 \\
\hline Pseudo $R^{2}$ & 0.204 & 0.225 & 0.246 & 0.201 & 0.222 & 0.238 \\
\hline
\end{tabular}

Dependent Variable: FIT dummy.

Standard errors in parentheses and clustered by country.

All models include OECD and EU dummies, region fixed effects, and a cubic time polynomial.

${ }^{*} p<0.10,{ }^{* *} p<0.05,{ }^{* * *} p<0.01$

Table 2: Results from logit model for FIT adoption in democratic subsample, 1990-2012. 